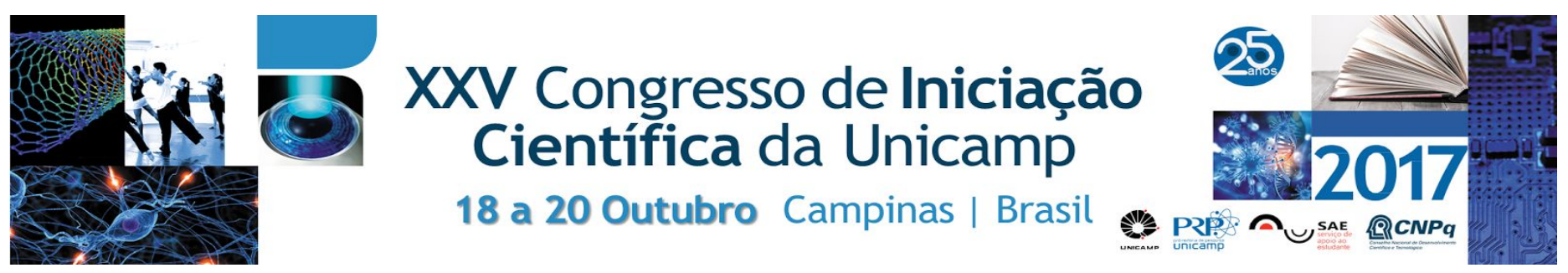

\title{
Uma ferramenta de auxílio ao ensino de música.
}

\author{
Leandro F. do Nascimento Júnior*, Ulisses M. Dias.
}

\section{Resumo}

Desenvolvemos um aplicativo para facilitar o aprendizado de leitura de partituras, uma habilidade desejável para profissionais do segmento musical. O aplicativo é uma alternativa ao modelo tradicional de ensino de teoria musical, permitindo que o estudante utilize apenas um smartphone e o próprio instrumento musical. A proposta é usar jogos para oferecer uma forma divertida e simples de praticar a leitura de partituras. Para usar o aplicativo o estudante deve emitir com o seu instrumento as notas indicadas durante os jogos.

Palavras-chave: Música, Dispositivos Móveis, Gamificação.

\section{Introdução}

Muitos profissionais e amadores do segmento musical são excelentes músicos mesmo sem a noção de leitura de partituras. Entretanto, esta habilidade abre diversas portas como o acesso a um rico repertório de músicas que utilizam essa notação. O processo para obter esse conhecimento pode ser frustrante, pois apesar de o conceito de localização das notas musicais na partitura ser simples, aprender a identificar essas notas com a fluência necessária para ler uma peça musical complicada pode levar tempo.

Diante dessa realidade, foi identificada a oportunidade de construir uma ferramenta que facilite o processo de aprendizagem. Esta ferramenta é um aplicativo que pode ser utilizado em qualquer smartphone android e tem o objetivo de ser uma alternativa simples para os estudantes de música realizarem os seus estudos.

A construção do aplicativo foi inspirada em tornar o processo de aprendizado mais atrativo e divertido, por meio da apresentação de estímulos visuais e desafios . O aplicativo permite ao estudante verificar o seu nível de fluência na leitura de partituras, identificando suas dificuldades e sanando-as enquanto se diverte jogando um dos jogos disponíveis.

\section{Resultados e Discussão}

O aplicativo tem o objetivo de treinar, por repetição e de uma maneira mais lúdica, a leitura de partitura. $\mathrm{O}$ usuário do aplicativo interage com os jogos por meio do microfone do aparelho. Nesse caso, a ferramenta é ideal para vários instrumentos. O aplicativo detecta o som emitido e computa a nota musical. Esta nota musical pode ser vista como uma ação realizada pelo jogador nos jogos disponíveis. As diferenças nos jogos são sutis, mas estas diferenças fazem o tempo disponível para o usuário emitir as notas variar conforme a dificuldade do jogo.

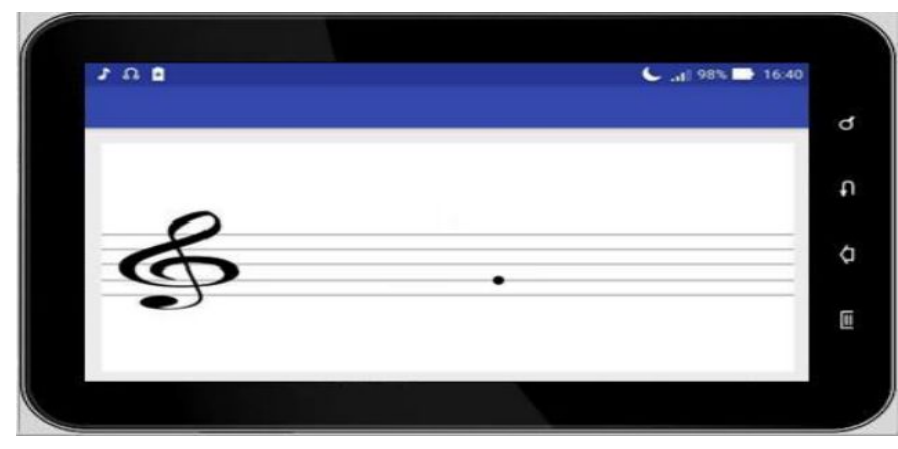

Figura 1. Aplicativo desenvolvido durante o projeto.

\section{Conclusões}

Disponibilizamos uma ferramenta que atende uma necessidade específica de profissionais e amadores do segmento musical. O aplicativo desenvolvido é um protótipo que visa demonstrar que é possível utilizar smartphones para benefícios da educação musical. Este projeto será continuado aprimorando os estímulos visuais apresentados, de forma a aumentar o impacto das estratégias de gamificação aplicadas na curva de aprendizagem do estudante.

Lecheta, Ricardo R. Google Android. Aprenda a criar aplicações para dispositivos móveis com Android SDK. 5 ed. São Paulo: Novatec, 2015. 1072 p.

Glauber Nelson, Dominando o Android: Do Básico ao Avançado.São Paulo: Novatec, 2015. 789 p. 